\title{
Trade Competitiveness of Agroforestry Crop Sector in Sri Lanka
}

\author{
S. Thamiem*, J. Weerahewa ${ }^{1}$, D.K.N.G. Pushpakumara ${ }^{2}$ and V.P. Singh ${ }^{3}$ \\ Postgraduate Institute of Agriculture \\ University of Peradeniya \\ Sri Lanka
}

\begin{abstract}
A significant change in the composition of agricultural exports from major plantation crops to non-traditional tree crops such as spices, fruits, and timber which mainly originated from small holder agroforestry systems is evident during the last few decades in Sri Lanka. Development of supply chain for products that are competitive in the world market will enable small holder farmers to reap the economic benefits from agroforestry systems and will make such systems economically viable. The objective of this work was to analyze the trade competitiveness of agroforestry crop sector in the country. Revealed Comparative Export Advantage (RXA), Relative Trade Advantage (RTA) and Revealed Comparative Advantage (RCA) indices were computed for 580 agroforestry products using data extracted from the trade map at the HS level 6 . The 580 products were grouped into 82 categories based on the crop origin. The analysis revealed that on average, 58 products had both relative export advantage and revealed comparative advantage and 124 products had relative trade advantage at HS 6 level during 2001-2008. Among the non-traditional exports, fruit crops (avocado, papaya, citrus, pineapple, cashew, lemon and lime, guava, mango, mangosteen and durian), root crops (manioc and arrowroot), medicinal plants (ginger and turmeric), cardamom, coffee, mushroom, bamboo, vanilla, cocoa and beans were found to be competitive in the world market according to relative trade advantage index. Cinnamon fetched the highest RXA, RTA and RCA values, followed by tea, cloves, coconut and nutmeg. The United Arab Emirates, France and Germany were found to be the major export destinations for the products that are highly competitive.
\end{abstract}

Key words: Agroforestry, Comparative advantage, Sri Lanka.

\section{INTRODUCTION}

A significant change in the composition of agricultural exports from major traditional plantation crops (i.e. tea, rubber and coconut) to non-traditional agricultural crops (i.e. spices, coffee, arecanuts, cashew nuts, vegetables and fruits) which mainly originate from small holder agroforestry systems has been evident in Sri Lanka during the last few decades. The values of exports of tea, rubber, coconut and other agricultural crops as shares of value of total agricultural exports changed from $68.7 \%, 10.7 \%, 9.6 \%$ and $11.1 \%$ to $68.6 \%, 6.7 \%$, $9.2 \%$ and $15.5 \%$, respectively from 1990 to 2009 (Central Bank, 2009).

\footnotetext{
To whom correspondence should be addressed : shanaz67@gmail.com

Department of Agricultural Economics and Business Management, Faculty of Agriculture, University of Peradeniya, Peradeniya, Sri Lanka

Department of Crop Science, Faculty of Agriculture, University of Peradeniya, Peradeniya, Sri Lanka

Regional Representative for South Asia, World Agroforestry Centre (ICRAF)
} 
Identification of products which are highly competitive in the world market and identification of the markets for such products are the first steps in development of value chains for crops. A large body of literature exists in this regard and it has been analyzed and assessed at different levels, i.e., micro (firm), meso (sector), and macro (nation) levels. At the micro-level, export competitiveness was defined as the ability of a firm to compete in domestic and international markets. A firm will be said to be competitive if it can produce products and services of superior quality, at lower costs than its domestic and international competitors (Buckley et al., 1988). At the meso and macro levels, a country's competitiveness is defined as the ability to compete or produce goods that meet the test of international markets, while simultaneously maintaining and expanding the real income of its citizens (Samen, 2010). Prasad (2004) examined the trade competitiveness in Fiji from 1998 to 2002 where he concludes that Fiji has a narrow range of competitive products in terms of its exports. Málaga and Williams (2006) analyzed the export performance of the Mexican agricultural and food sector in recent years with a particular emphasis on the changing competitiveness of those exports in the US and world markets. Utkulu and Seymen (2004) analysed the competitiveness and the pattern of trade flows/trade specialization from Turkey to the EU on sectoral levels. Stefan and Imre (2009) investigates the level, composition, and differences in agro-food relative trade advantages and disadvantages for eight Central European and Balkan countries on the European Union (EU) markets and their implications for food policy. Samaratunga and Thibbotuwawa (2006) revealed that Sri Lanka is competitive for fish and crustaceans, plantation crops, spices, cut flowers, vegetables and oil seeds among the agricultural products.

Despite the economic, agronomic and environmental significance of agroforestry systems, no studies have been conducted to evaluate export competitiveness of products that originate from such systems. Agroforestry systems, which are defined as a dynamic, ecological based, natural resources management system that, through the integration of trees on farms and in the agricultural landscape, diversifies and sustains production for increased social, economic and environmental benefits for land users at all levels, are now being seen as an alternative paradigm for rural development worldwide, that is centered on species rich, low input agricultural techniques including a diverse array of new indigenous tree crops, rather than on high input monoculture with only a small set of staple food crops (Leakey, 2001). It is a sustainable land use system that combines natural or planted trees and shrubs with crops and/or livestock on the same unit of land while conserving natural resources and increase and diversify the farm and forest production. Agroforestry systems, particularly in tropics, comprise of various types of tree-based systems that are available for farmers such as treecrops, orchards, home gardens, pastures, fuel wood lots, timber trees, shelterbelts. (FAO, 2010). Given the above definition, except the area under large scale plantation crops (tea, rubber, coconut), all the other small to medium scale cropping systems in Sri Lanka can be considered as agroforestry systems and 29 such systems have been described in Sri Lanka (Nanayakkara, 1991). Sri Lanka is famous for well known agroforestry systems such as Kandyan homegardens (Jacob and Alles, 1987; Perera and Rajapakse, 1991). Pushpakumara (2007) has given a detail account of agroforestry systems in Sri Lanka.

In this context, the objectives of the study were to analyze the competitiveness of agroforestry products in Sri Lanka using the Revealed Comparative Export Advantage (RXA), Relative Trade Advantage (RTA) and Revealed Comparative Advantage (RCA), identify the major export destinations, and identify the import tariff restrictions, if any, for products that are highly competitive in the export market. 


\section{METHODOLOGY}

A number of indices exist in the literature to evaluate the degree of competitiveness of tradable products. The most widely used index is the Revealed Comparative Advantage (RCA) which was introduced by Balassa (1965). It is expressed as the ratio of share of export of a particular product to total value of export of the country under consideration to that of the rest of the world. Revealed Comparative Advantage is used widely owing to its simplicity in calculation and easiness in interpretation (Langhammer, 2004). Many studies have used the RXA as a measure of export competitiveness in both merchandise trade (Amiti, 1998; Proudman and Redding, 2000; Hinloopen and Van Marrewijk, 2001; Utkulu and Seymen, 2004; Prasad, 2004) and agricultural trade (Eiteljörge and Hartmann, 1999; Bojnec, 2001; Ferto and Hubbard, 2003; Málaga and Williams, 2006).

$$
\operatorname{RCA}_{i j}=\left(X_{i j} / \sum_{j=1}^{n, n \neq j} X_{i n}\right) /\left(\sum_{i=1}^{m, m \neq i} X_{m j} / \sum_{i=1}^{m, m \neq i} \sum_{j=1}^{n, n \neq j} X_{n m}\right)
$$

where,

$\mathrm{X}$ represents the trade value, $i$ is a country, $j$ is a product, $n$ is the number of products traded and $m$ is the number of countries in the world.

If $\mathrm{RCA}>1$, comparative advantage is revealed. If RCA $<1$, the country is said to have a comparative disadvantage. The index, by definition, is sensitive to both the number and classification of countries and industries (Andreosso, 2009). Furthermore, the product $i$ is double counted in the denominator for both the country under consideration and the rest of the world. As an alternative to RCA, Relative Trade Advantage (RTA) and the Relative Export Advantage (RXA) indices are being used (Vollrath, 1991 and Stefan and Imre, 2009).

The RXA is defined as:

$$
\operatorname{RXA}_{i j}=\left(X_{i j} / \sum_{j=1}^{n, n \neq j} X_{i n}\right) /\left(\sum_{i=1}^{m, m \neq i} X_{m j} / / \sum_{i=1}^{m, m \neq i} \sum_{j=1}^{n, n \neq j} X_{n m}\right)
$$

where,

$\mathrm{X}$ represents the export value, $i$ is a country, $j$ is a product, $n$ is the number of products exported and $m$ is the number of countries in the world.

RXA also measures exports of a product by a country relative to its total exports and to the corresponding export performance of a set of countries. To avoid double counting, the product $j$ and the country $i$ are excluded in the denominator, respectively. If RXA $>1$, then a comparative export advantage is revealed.

On the other hand, RTA index considers both imports and exports simultaneously and it is represented by,

$$
\mathrm{RTA}_{i j}=\mathrm{RXA}_{\mathrm{ij}}-\mathrm{RMA}_{i j}
$$

where,

$$
\mathrm{RMA}_{i j}=\left(M_{i j} / \sum_{j=1}^{n, n \neq j} M_{i n}\right) /\left(\sum_{i=1}^{m, m \neq i} M_{m j} / / \sum_{i=1}^{m, m \neq i} \sum_{j=1}^{n, n \neq j} M_{n m}\right)
$$


and M represents the export value, $i$ is a country, $j$ is a product, $n$ is the number of products imported and $m$ is the number of countries in the world.

If RTA $>0$, a relative trade advantage is revealed, i.e. a sector in which the country's trade is relatively more competitive. RTA $<0$ refers to all those product groups with an absence of relative trade advantage. RTA $=0$ refers to all those product groups at a break-even point without relative trade advantage or relative trade disadvantage (Vollrath, 1991).

\section{Data and data sources}

The values of exports and imports pertaining to Sri Lanka and rest of the world were collected from the Trade at Harmonized System (HS) 6 level $^{4}$ for the period 2001-2008.

Of the 99 HS categories at the second level, 19 were selected as relevant for the analysis. EC-FAO (2002) and Census of Agriculture (2002) were used to identify crops which originate from the agroforestry systems. The $19 \mathrm{HS}$ categories selected included products under HS categories 06, 07, 08, 09, 12, 13, 14, 15 (excluding animal fats and oil), 18, 20, 21, $22,23,40,44,45,47,48$ and 94 (excluding metal and plastic furniture).

The products with export values of zero were excluded from the analysis and RXA, RTA and RCA were computed for 580 products. Subsequently, the raw materials and the value added products of each crop were identified from the list and 82 composite crop categories were formed. The list of composite crop categories and their relevant HS codes used to calculate the average competitive indices are given in the Table 2.

\section{RESULTS AND DISCUSSION}

\section{Export Shares and Export Destinations}

Under HS02 digit product disaggregation, the selected 19 categories of products and their relative export share to the total export of Sri Lanka during 2001-2008 are presented in Table 1.

Table 1. HS categories at 2 digit disaggregation selected for the study with the export share

\begin{tabular}{|c|c|c|c|c|c|c|}
\hline Product label & 2001 & 2002 & 2003 & 2004 & 2005 & 2008 \\
\hline HS06 Live trees, plants, bulbs, roots, cut flowers etc & 0.17 & 0.17 & 0.20 & 0.16 & 0.16 & 0.17 \\
\hline HS07Edible vegetables and certain roots and tubers & 0.14 & 0.15 & 0.15 & 0.18 & 0.19 & 0.31 \\
\hline HS08Edible fruit, nuts, peel of citrus fruit, melons & 0.91 & 0.84 & 0.99 & 1.15 & 0.85 & 1.17 \\
\hline HS09Coffee, tea and spices & 15.98 & 15.80 & 15.30 & 14.75 & 14.63 & 17.28 \\
\hline HS12 Oil seed, oleagic fruits, grains, seeds, fruits, etc. & 0.20 & 0.24 & 0.28 & 0.25 & 0.26 & 0.19 \\
\hline HS13 Gums, resins, vegetable saps and extracts & 0.02 & 0.02 & 0.02 & 0.02 & 0.02 & 0.02 \\
\hline HS14 Vegetable plaiting materials, vegetable products & 0.05 & 0.07 & 0.09 & 0.09 & 0.08 & 0.16 \\
\hline S15 Animal, vegetable fats and oils, cleavage products, etc & 0.09 & 0.10 & 0.18 & 0.36 & 2.35 & 0.74 \\
\hline HS18Cocoa and cocoa preparations & 0.01 & 0.00 & 0.01 & 0.00 & 0.00 & 0.01 \\
\hline \multicolumn{7}{|c|}{ Table continued on next page } \\
\hline \multicolumn{7}{|c|}{$\begin{array}{l}\text { HS is an international nomenclature for the classification of a country's traded goods on a common basis for } \\
\text { customs purposes. At the international level, the HS is a six-digit code system comprising of product } \\
\text { descriptions that appear as headings and subheadings. The first two digits identify the chapter the goods are } \\
\text { classified in, the next two digits identify groupings within that chapter and the next two digits are even more } \\
\text { specific in the six digits code system (Trade Map, 2009). }\end{array}$} \\
\hline
\end{tabular}


HS20 Vegetables, fruits, nuts, etc. food preparations

HS21 Miscellaneous edible preparations

HS22 Beverages, spirits and vinegar

HS23 Residues, wastes of food industry, animal fodder

HS40 Rubber and articles thereof

HS44 Wood and articles of wood, wood charcoal

HS45 Cork and articles of cork

HS47 Pulp of wood, fibrous cellulosic material, waste etc

HS48 Paper \& paperboard, articles of pulp, paper and board

HS94Furniture, lighting, signs, prefabricated buildings

\begin{tabular}{llllll}
0.00 & 0.00 & 0.00 & 0.00 & 0.00 & 0.00 \\
0.24 & 0.26 & 0.30 & 0.25 & 0.20 & 0.42 \\
0.04 & 0.04 & 0.04 & 0.04 & 0.05 & 0.05 \\
0.17 & 0.32 & 0.34 & 0.34 & 0.25 & 0.78 \\
4.20 & 4.43 & 5.54 & 6.11 & 7.17 & 8.15 \\
0.23 & 0.27 & 0.39 & 0.50 & 0.50 & 0.52 \\
0.00 & 0.00 & 0.00 & 0.00 & 0.00 & 0.00 \\
0.09 & 0.10 & 0.16 & 0.18 & 0.17 & 0.23 \\
0.31 & 0.38 & 0.40 & 0.26 & 0.30 & 0.27 \\
0.17 & 0.23 & 0.22 & 0.23 & 0.22 & 0.40 \\
\hline
\end{tabular}

The share of export value of category HS 09 is the highest followed by HS categories 40,08 , 47, 48, 23, 21 and 12. Most of these categories included the non-traditional crops that are cultivated in small holdings. Table 3 depicts the major export destinations by the export values in the year 2009 for the 19 categories selected for this analysis at the HS 02 level. Of the 19 HS categories, India imports products from eight categories and acts as a major importer followed by United Arab Emirates which imports products from seven categories and Maldives which imports products from five categories.

\section{Trade competitiveness}

At HS 6 level product disaggregation the RXA, RTA and RCA values were calculated from 2001 to 2008 using export and import values. Based on the values of above indices, the number of products that are competitive in the world market was obtained. Table 2 presents the summary of the results.

Table 2. Number of competitive products at HS 6 level disaggregation

\begin{tabular}{llcccccc}
\hline Competitiveness indices & $\mathbf{2 0 0 1}$ & $\mathbf{2 0 0 2}$ & $\mathbf{2 0 0 3}$ & $\mathbf{2 0 0 4}$ & $\mathbf{2 0 0 5}$ & $\mathbf{2 0 0 8}$ \\
\hline \multirow{3}{*}{ RXA } & Number of competitive & 52 & 58 & 61 & 61 & 57 & 57 \\
& products & $(10.59)$ & $(10.36)$ & $(10.89)$ & $(10.89)$ & $(10.20)$ & $(9.90)$ \\
& Total number of products & 491 & 560 & 560 & 560 & 559 & 576 \\
& Number of competitive & 120 & 113 & 120 & 128 & 132 & 133 \\
RTA & $(24.29)$ & $(20.18)$ & $(21.43)$ & $(22.86)$ & $(23.57)$ & $(22.97)$ \\
& products & 494 & 560 & 560 & 560 & 560 & 579 \\
& Total number of products & 52 & 58 & 61 & 61 & 57 & 57 \\
& Number of competitive & $(10.59)$ & $(10.36)$ & $(10.89)$ & $(10.89)$ & $(10.20)$ & $(9.90)$ \\
RCA & products & 491 & 560 & 560 & 560 & 559 & 576 \\
& Total number of products & & & & & & \\
\hline
\end{tabular}

Values in the parentheses are the percentage of competitive products out of the products that have data for each year

The numbers of products that have relative export advantage and relative competitive advantage at HS 6 level are exactly the same. However, the products that have revealed trade advantage is more than double compared to those of RXA and RCA. On average, 58 products had both relative export advantage and revealed comparative advantage and 124 products had relative trade advantage over the years at HS 6 level.

Table 3 shows the HS 6 level products which are aggregated based on crop origin and their RXA values over the years. 
Table 3. RXA of composite crops that are competitive in the world market

\begin{tabular}{lcccccc}
\hline Composite crop category & $\mathbf{2 0 0 1}$ & $\mathbf{2 0 0 2}$ & $\mathbf{2 0 0 3}$ & $\mathbf{2 0 0 4}$ & $\mathbf{2 0 0 5}$ & $\mathbf{2 0 0 8}$ \\
\hline Cinnamon & 146.76 & 152.74 & 184.65 & 161.42 & 163.15 & 155.87 \\
Tea & 224.00 & 230.77 & 205.92 & 186.49 & 143.22 & 146.42 \\
Cloves & 22.86 & 71.51 & 21.10 & 37.07 & 52.71 & 76.77 \\
Nutmeg & 16.24 & 22.96 & 28.97 & 20.25 & 22.84 & 25.05 \\
Coconut & 16.01 & 16.83 & 17.35 & 19.47 & 12.28 & 11.55 \\
Pepper & 3.83 & 11.30 & 10.41 & 7.60 & 8.75 & 8.42 \\
Rubber & 1.47 & 1.55 & 1.88 & 1.95 & 2.01 & 1.90 \\
Papaya & n.a & n.a & n.a & n.a & n.a & 1.70 \\
Beans & n.a & n.a & n.a & n.a & n.a & 1.25 \\
Other seeds and spices & n.a & n.a & n.a & n.a & n.a & 1.03 \\
Curry leaves & 7.69 & 9.47 & 9.88 & 8.37 & 9.01 & n.a \\
Cucumber & n.a & 1.08 & 1.06 & 1.23 & 1.05 & n.a \\
Natural gums \& resins & n.a & n.a & 1.09 & n.a & n.a & n.a \\
\hline
\end{tabular}

n.a: data not available

From 2001 to 2004, tea was on the top of the list and during 2005 and 2008 cinnamon fetched the highest RXA values, followed by tea, cloves, nutmeg and coconut.

RCA indices calculated for the composite crop products at HS 6 level are given in Table 4. It shows that cinnamon is the most competitive product followed by tea in all the years except in 2008. Clove, nutmeg, coconut and pepper are the next most competitive products according to RCA index.

Table 4. RCA of composite crops that are competitive in the world market

\begin{tabular}{lcccccc}
\hline \multirow{2}{*}{ Composite Crop Category } & $\mathbf{2 0 0 1}$ & $\mathbf{2 0 0 2}$ & $\mathbf{2 0 0 3}$ & $\mathbf{2 0 0 4}$ & $\mathbf{2 0 0 5}$ & $\mathbf{2 0 0 8}$ \\
\hline Cinnamon & 141.03 & 146.57 & 177.74 & 155.94 & 157.56 & 150.86 \\
Cloves & 22.60 & 69.71 & 21.00 & 36.70 & 52.18 & 75.80 \\
Tea & 81.31 & 93.72 & 88.64 & 85.97 & 74.99 & 74.32 \\
Nutmeg & 16.18 & 22.85 & 28.82 & 20.18 & 22.74 & 24.96 \\
Coconut & 15.33 & 16.09 & 16.52 & 18.44 & 11.83 & 11.08 \\
Pepper & 3.81 & 11.16 & 10.31 & 7.56 & 8.69 & 8.34 \\
Papaya & n.a & n.a & n.a & n.a & n.a & 1.70 \\
Rubber & 1.38 & 1.45 & 1.68 & 1.72 & 1.75 & 1.67 \\
Beans & n.a & n.a & n.a & n.a & n.a & 1.24 \\
Curry leaves & 7.69 & 9.46 & 9.87 & 8.36 & 9.01 & n.a \\
Cucumber & n.a & 1.08 & 1.06 & 1.22 & 1.05 & n.a \\
Natural gums and resins & n.a & n.a & 1.09 & n.a & n.a & n.a \\
\hline
\end{tabular}

n.a: data not available

Though Sri Lanka is traditionally engaged in exportation of the plantation crops and spices (cinnamon, cloves, nutmeg and pepper), the other non-traditional crops for example fruit crops (avocado, papaya, citrus, pineapple, cashew, lemon and lime, guava, mango and mangosteen and durian), root crops (manioc and arrowroot), medicinal plants (ginger and 
turmeric), cardamom, coffee, mushroom, bamboo, vanilla, cocoa and beans revealed trade competitiveness in the world market. Furthermore, various forms of preserved vegetables, wood products, wood pulp, cut flower and bamboo were also found to be competitive in the world market (Table 4).

\section{Export destinations and import tariff barriers}

An examination of the main export destinations of the crops that were competitive in the world market with the recent export value in the year 2009 as well as the trade restriction, especially the import tariff imposed by the main importing countries, it was noted that the major export destinations of Sri Lankan non traditional crop products are the United Arab Emirates, Pakistan and Saudi Arabia. UAE imported six out of 10 crop products, i.e. manioc and arrowroot, papaya, pineapple, guava, mango and mangosteen.

Table 5. Ten non-traditional crop products and the tariff imposed by the major export destinations

\begin{tabular}{|c|c|c|c|}
\hline Crop products & Importers & $\begin{array}{c}\text { Number } \\
\text { of lines }\end{array}$ & $\begin{array}{l}\text { Total ad Valorem } \\
\text { Equivalent Tariff } \\
\text { (estimated \%) }\end{array}$ \\
\hline Cinnamon and cinnamon-tree & Mexico & 3 & 10 \\
\hline \multirow[t]{2}{*}{ flowers } & United States of America & 3 & 0 \\
\hline & Colombia & 3 & 15 \\
\hline \multirow[t]{3}{*}{ Cloves } & India & 4 & 0 \\
\hline & United States of America & 1 & 5 \\
\hline & United Kingdom & 1 & 0 \\
\hline Pepper of the genus Piper, ex cubeb & India & 9 & 70 \\
\hline \multirow[t]{3}{*}{ pepper, neither crushed nor ground } & United States of America & 1 & 0 \\
\hline & Pakistan & 4 & 1.24 \\
\hline & United Arab Emirates & 9 & 70 \\
\hline \multirow[t]{3}{*}{ Avocados (dried) } & Qatar & 4 & 1.24 \\
\hline & Saudi Arabia & 1 & 0 \\
\hline & United Arab Emirates & 2 & 0 \\
\hline \multirow[t]{3}{*}{ Papaya (fresh) } & Japan & 1 & 0 \\
\hline & Austria & 2 & 0 \\
\hline & United Arab Emirates & 3 & 5 \\
\hline \multirow[t]{3}{*}{ Manioc } & United Kingdom & 2 & 4.75 \\
\hline & Kuwait & 3 & 5 \\
\hline & United Arab Emirates & 1 & 0 \\
\hline \multirow[t]{3}{*}{ Arrowroot } & Canada & 1 & 0 \\
\hline & Bahrain & 1 & 0 \\
\hline & Germany & 1 & 0 \\
\hline \multirow[t]{2}{*}{ Pineapples, fresh or dried } & United Arab Emirates & 1 & 0 \\
\hline & France & 1 & 0 \\
\hline \multirow{4}{*}{$\begin{array}{l}\text { Cashew nuts, without shell, fresh or } \\
\text { dried }\end{array}$} & France & 1 & 0 \\
\hline & Japan & 1 & 0 \\
\hline & Malaysia & 3 & 0 \\
\hline & Germany & 1 & 0 \\
\hline \multirow[t]{2}{*}{ Guava, Mangoes and Mangosteen } & The United Arab Emirates & 3 & 9.38 \\
\hline & Japan & 1 & 0 \\
\hline
\end{tabular}

Source: Trade Map and Market Access Map 
Import tariffs are charged by some of the countries. Pepper and manioc were the crops that faced the import tariff from all the countries of import. Papaya, pineapple, guava, mango, mangosteen and avocados experience import tariff from some of the importing countries. Import tariff ranges from $0 \%$ to $70 \%$. For fruits the range is from $0.83 \%$ to $70 \%$ and for root crops it ranges from $4.75 \%$ to $5 \%$ (Table 5 ).

\section{CONCLUSIONS}

Trade competitiveness indices were computed for 580 products at HS level 6 which have an agroforestry origin and were aggregated at crop levels to examine products from which crops are competitive in the world market. The results revealed that though the traditional plantation crops show the highest competitive values, a number of non-traditional crops that are grown as small holding crops such as spices (cinnamon, cardamom, nutmeg, curry leaves and pepper), fruit crops (papaya, pineapple, guava, mango, mangosteen, avocado, banana, cashew, lime, lemon and durian) and some root crops (manioc and arrowroot) also experience competitiveness in the world market. In addition, various forms of preserved vegetables, wood products, wood pulp, cut flowers and bamboo also showed trade competitiveness. It was noted that among the major export destinations of Sri Lankan nontraditional competitive crop products, the United Arab Emirates had the potential to import most of the crops followed by the United States of America, Japan, France and Germany. The import tariffs charged by some of the above importing countries range from $0 \%$ to $70 \%$. These results provide an insight to the farmers to decide on what individual crops can be grown in order to reap economic benefits. The study recommends promotion of agroforestry systems in Sri Lanka as potential sector where most of the non-traditional crops such as spices, fruit crops and root crops are grown. Further research is needed to examine non-tariff barriers to exports such as sanitary and quality standards on such products

\section{ACKNOWLEDGEMENT}

The authors thank the financial support from the World Agroforestry Center to carry out this study.

\section{REFERENCES}

Andreosso-O'Callaghan B. (2009). Economic Structural Complementarity: How Viable is the Korea-EU FTA?, Ireland J. Econ. Stud. 36. 147-167.

Balassa, B. (1965). Trade liberalization and revealed comparative advantage. The Manchester School of Economic and Social Studies. 33, 99-123.

Central Bank of Sri Lanka, Annual Report (2009). Colombo, Sri Lanka.

Central Bank of Sri Lanka, Annual Reports, various years, Colombo, Sri Lanka.

Census of Agriculture (2002). Agriculture and Environment Statistics Division, Department of Census and Statistics of Sri Lanka. 
EC-FAO Partnership Program, (2000-2002). Tropical Forestry Budget Line B7201/1b/98/0531, Project Gcp/Ras/173/, Assessment of Tree Resources in the Home Gardens of Sri Lanka.

FAO (2010). Agroforestry systems [on line]. [Accessed on 13.05.2010]. Available at http://www.fao.org/forestry/9469/en/

Jacob, V.J. and Alles, W.S. (1987). Kandyan Gardens of Sri Lanka, Agroforestry Systems. 5, 123-137.

Leakey, R.R.B. (2001). Win:win landscape strategies for Africa. Building on experience with agroforests in Asia and Latin America. Int. Forestry Rev. 3, 1-10.

Market Access Map, International Trade Centre UNCTAD / WTO (ITC) [on line], [Downloaded on 03.11.2009], Available at http://www.macmap.org/

Nanayakkara, V.R. (1991). Agroforestry systems in Sri Lanka. In W. Mellink, E S. Rao, and K. G. MacDicken (Eds) Agroforestry in Asia and the Pacific. RAPA Publication 199115. FAO Regional Office for Asia and the Pacific (RAPA) and Winrock International Institute for Agricultural Development. Bangkok, Thailand. pp. 148-167.

Perera, A.H. and Rajapakse, R.M.N. (1991). A Baseline study of Kandyan Forest Gardens of Sri Lanka: Structure, composition and utilization. Forestry Ecol. and Mgt. 45, 269-280.

Pushpakumara, D.K.N.G. (2008). Agroforestry systems in Sri Lanka: Self Learning Guide. World Agroforestry Centre, ICRAF South Asia Program, New Delhi, India

Samaratunga, P. and Thibbotuwawa, M. (2006). Mapping and Analysis of South Asian Agricultural Trade Liberalization Effort. Asia-Pacific Research and Training Network on Trade Working Paper Series, 26, December.

Stefan, B. and Imre, F. (2009). Agro-food trade competitiveness of Central European and Balkan countries. Food Policy. 34, 417-425.

Trade Map, International Trade Centre UNCTAD / WTO (ITC) [on line], [Accessed on 15.11.2009], Available at http://www.trademap.org/stGlossary.aspx

Trade Map, International Trade Centre UNCTAD / WTO (ITC) [on line], [Accessed on 16.11.2009], Available at http://www.trademap.org

Vollrath, T.L. (1991). A Theoretical Evaluation of Alternative Trade Intensity Measures of Revealed Comparative Advantage. Weltwirtschaftliches Archiv. 130, 265-79.

Samen, S, (2010). Export Development, Diversification, and Competitiveness: How Some Developing Countries got it Right, Growth and Crisis Unit, World Bank Institute.

Buckley, P.J., Pass C.L. and Prescott, K. (1988). Measures of International Competitiveness: A critical survey, J. Marketing Management, 4, 20.

Prasad, R. (2004). Fiji's Export Competitiveness: A Comparison with Selected Small Island Developing States, Working Paper, Economics Department, Reserve Bank of Fiji. 
Málaga, J.E. and Williams, G.W. (2006). Mexican Agricultural and Food Export Competitiveness, TAMRC International Market Research Report, No. IM-01-06.

Utkulu, U. and Seymen, D. (2004). Revealed Comparative Advantage and Competitiveness: Evidence for Turkey vis-à-vis the EU/15, Presented at the European Trade Study Group 6th Annual Conference, ETSG 2004, Nottingham, September 2004.

Langhammer, R.J. (2004). Revealed Comparative Advantages in Service Trade of the USA, EU, and Japan. What Do They Tell Us, J. World Investment and Trade, 5, 887-896.

Amiti, M. (1998). New trade theories and industrial location in the EU, Oxford Rev. of Econ. Policy, 14(2), 45-53.

Proudman, J. and Redding, S. (2000). Evolving patterns of international trade, Rev. of Int. Econ. 8, 373-396.

Hinloopen, J. and Van Marrewijk, C. (2001). On the empirical distribution of the Balassa Index, Weltwirtschaftliches Archive, 137(1), 1-35.

Eiteljörge, U. and Hartmann, C. (1999). Central and Eastern European food chain competitiveness, In The European Agro-food System and the Challenge of Global Competition, The International Food and Agribusiness Management Association (ISMEA), Rome, pp. 187-224.

Bojnec, Š. (2001). Trade and Revealed Comparative Advantage Measures: Regional and Central and East European Agricultural Trade, East. Europ. Econ. 39(2), 72-98.

Ferto, I. and Hubbard, L.J. (2003). Revealed comparative advantage and competitiveness in Hungarian agri-food sectors, The World Econ. 26(2), 247-259. 